Published in final edited form as:

Adv Exp Med Biol. 2012 ; 739: 187-205. doi:10.1007/978-1-4614-1704-0_12.

\title{
NEUROBIOLOGY OF SOCIABILITY
}

\author{
Heather K. Caldwell \\ Laboratory of Neuroendocrinology and Behavior, Department of Biological Sciences and School \\ of Biomedical Sciences, Kent State University, Ohio, USA \\ Heather K. Caldwell: hcaldwel@kent.edu
}

\begin{abstract}
Sociability consists of behaviors that bring animals together and those that keep animals apart. Remarkably, while the neural circuitry that regulates these two "faces" of sociability differ from one another, two neurohormones, oxytocin (Oxt) and vasopressin (Avp), have been consistently implicated in the regulation of both. In this chapter the structure and function of the Oxt and Avp systems, the ways in which affiliative and aggressive behavior are studied, and the roles of Oxt and Avp in the regulation of sociability will be briefly reviewed. Finally, work implicating Oxt and Avp in sociability in humans, with a focus on neuropsychiatric disorders will be highlighted.
\end{abstract}

\section{INTRODUCTION}

Sociability is the tendency to seek social interactions. Navigating a social environment is not easy; for instance, the ability to discriminate a male from a female will impact the decision to fight versus mate. Yet, behavior seems obvious, our understandings of the neurobiological mechanisms underlying sociability are just now coming to light. Interestingly, it is the lack of sociability found in several neuropsychiatric disorders, such as autism and schizophrenia that has been the impetus for much of the research in this area. ${ }^{1,2}$ To date, two neuropeptides, oxytocin (Oxt) and vasopressin (Avp), have been consistently linked with the neural regulation of sociability. With recent developments in behavioral tests to model aspects of sociability, the use of comparative studies, as well as the use of viral vectors and transgenic animals, including knockout mice, our understanding of the neural underpinnings of sociability is improving, as is our understanding of the contributions of Oxt and Avp. This chapter will focus on mammals and will review the behavioral components of sociability, describe the ways in which sociability is experimentally assessed, explore the contributions of Oxt and Avp to sociability and delve into some of the data on the neurobiology of altered sociability in human neuropsychiatric disorders.

\section{SOCIABILITY IN CONTEXT}

Social behavior is highly complex and varied, with some animals living in groups with complicated social structures while others are solitary and only engage in social interactions intermittently. Some of the questions researchers in this field have focused on include: Why does an animal engage in a social behavior in a specific context? What social or environment cues are required for a social exchange to occur? How does the brain regulate social interactions? 
Sociability can be separated into two categories: (1) behaviors that bring animals together, such as affiliative, parental, or copulatory behaviors and (2) behaviors that separate animals, such as aggressive behaviors. This review will focus on the neural regulation of affiliative and aggressive behaviors; for reviews on neural regulation of parental and copulatory behaviors, please see Hammock and Young, ${ }^{3}$ Lim and Young, ${ }^{4}$ McCarthy and colleagues. ${ }^{5}$

\section{MAJOR NEUROHORMONES IMPORTANT TO THE REGULATION OF SOCIABILITY}

The first biochemicals implicated in the regulation of sociability were the gonadal steroids. ${ }^{6}$ This hypothesis stemmed from research demonstrating that there were changes in sociability, particularly aggressive behavior, as a result of androgen manipulation, (e.g., castration or hormone replacement). There are also several species, particularly seasonal breeders, which continue to have elevated levels of aggressive behavior despite dramatic reductions in gonadal steroids. ${ }^{7-11}$ It seems that in many species gonadal steroids may be necessary, but not sufficient, to alter sociability. Rather, the neuropeptides Oxt and Avp have been implicated in the neural regulation of sociability and specifically differences in their receptor distributions appear to be of particular importance.

\section{The Nonapeptides: Oxytocin and Vasopressin}

Oxt and Avp are both nine amino acid neuropeptides (i.e., nonapeptides) synthesized primarily in the paraventricular nucleus (PVN) and supraoptic nucleus (SON) of the hypothalamus. Their genes sit in opposite transcriptional orientations on the chromosome as the result of the duplication of an ancestral vasotocin gene. ${ }^{12,13}$ Both genes are composed of three exons, differ from one another by only two amino acids and are synthesized as part of a larger precursor preprohormone. ${ }^{14}$ Since they are so structurally similar, Oxt and Avp are considered "sister" hormones though their actions both peripherally and centrally differ significantly from one another. Interestingly, Oxt and Avp are linked to several aspects of sociability and their actions appear to be fairly conserved across mammalian species. ${ }^{15-21}$

\section{Oxytocin}

Some of the early work on Oxt characterized its peripheral actions on the regulation of uterine contraction and milk ejection. ${ }^{22,23}$ It is its synthesis in larger, magnocellular neurons of the PVN and SON, which project to the posterior pituitary that mediate the aforementioned actions. Oxt synthesized in the smaller, parvocellular, neurons of the PVN project centrally and mediate many of the central actions of Oxt. In mice and various vole species there have also been reports of Oxt neurons outside of the PVN. ${ }^{24-26}$ For example, in female prairie voles (Microtus ochrogaster) Oxt immunoreactive (Oxt-ir) fibers that originate from both the PVN and SON have been found to innervate the nucleus accumbens (NAcc); the significance of which will be discussed later ${ }^{27}$

Thus far only a single Oxt receptor (Oxtr) has been identified and it is thought to transduce all of the actions of Oxt. ${ }^{28,29}$ The Oxtr is a member of the seven transmembrane G-proteincoupled receptor family; it is also structurally similar to the Avp receptors. ${ }^{30}$ Identification of Oxtr expression was initially determined with receptor autoradiography using a potent ${ }^{125}$ 
I-labeled antagonist. In rats and mice, Oxtr binding is found in several areas, including the hippocampal formation, lateral septum (LS), central amygdala (CeA), olfactory tubercle, nucleus accumbens shell, dorsal caudate-putamen, bed nucleus of the stria terminalis (BNST), medial amygdala (MeA) and ventromedial hypothalamus (VMH). ${ }^{31-33}$

\section{Vasopressin}

Avp's peripheral actions include the regulation of salt and water balance. Avp made in the magnocellular neurons of the PVN and SON is transported to the posterior pituitary and its release from the posterior pituitary regulates most of its peripheral actions. Centrally, Avp is also expressed in the suprachiasmiatic nucleus (SCN), BNST and MeA. ${ }^{34}$ There are also reports of Avp immunoreactive (Avp-ir) neurons in the medial septum, LS, vertical limb of the nucleus of the diagonal band of Broca and the locus coeruleus. ${ }^{35}$ Between the projections provided by the parvocellular vasopressinergic neurons of the PVN and the aforementioned nuclei, Avp fibers are extensive within the central nervous system ${ }^{36-39}$

Avp receptors can be divided into two classes: Avp1 and Avp2 receptors (Avpr1 and Avpr2, respectively), both of which are seven transmembrane G-protein-coupled receptors that are similar in structure to the Oxtr. There are two subtypes of the Avpr1: The Avpr1a and the Avpr1b. Peripherally, the Avpr1a mediates the effects of Avp on vasoconstriction and can be found in the liver, kidney, platelets and smooth muscle. ${ }^{40,41}$ Centrally, the Avpr1a is found in a variety of brain nuclei. ${ }^{42-45}$ The Avpr $1 \mathrm{~b}$ was originally described in the anterior pituitary, where is prominent on the corticotrophes; though, it can also be found in the brain. ${ }^{46,47}$ In rats, the Avpr $1 \mathrm{~b}$ has been localized to areas such as the olfactory bulb, piriform cortical layer II, LS, cerebral cortex, hippocampus, PVN, SCN, cerebellum and red nucleus, ${ }^{4-51}$ but initial immunohistochemical and in situ hybridization histochemistry (ISHH) studies may have used antibodies and probes that lacked specificity. ${ }^{52}$ In rats and mice however, the Avpr1b appears to be more discretely localized with prominent expression in the hippocampal field CA2 pyramidal neurons. ${ }^{52}$ The Avpr2 is found in the periphery and is primarily expressed in the kidney; it has not been localized to the brain. Its role in the kidney is to transduce the antidiuretic effects of Avp within the renal collecting ducts. .53

\section{SOCIAL BEHAVIORS}

On the surface, affiliative and aggressive behaviors appear to represent opposite ends of a behavioral spectrum and in fact, many of the neurotransmitters/neurohomones that regulate affiliative and aggressive behaviors are the same. However, the neuroanatomical substrates on which they act differ, suggesting that the neural circuits that underlie affiliative and aggressive behaviors differ significantly from one another. In this section, the defining features of affiliative and aggressive behaviors, how they are experimentally tested and their neural regulation will be explored.

\section{Affiliative Behavior}

Affiliative behaviors are those that include social bonding between individuals, including bonds between mates and parents with their offspring. From an evolutionary, perspective 
social bonds serve to reduce stress and anxiety by increasing security. ${ }^{54,55}$ As most mammalian species are social, the formation of social bonds aids in holding groups or pairs of individuals together.

Social bonds have been studied extensively in primates and in some instances have been shown to increase evolutionary fitness. ${ }^{56}$ For example, in a group of free-ranging baboons, females that have strong social bonds with one another live longer than those who have weaker social bonds. ${ }^{57}$ In other mammals the direct effect of social bonding on fitness has been less studied, though a recent study in feral horses did find that in unrelated females, social bonding improved reproductive success. ${ }^{58}$ So, it may be that for many species, social bonding has a direct benefit on fitness and that it simply has not been adequately studied across species.

The proximate cause, i.e., the neural regulation, of social bonds between male and female

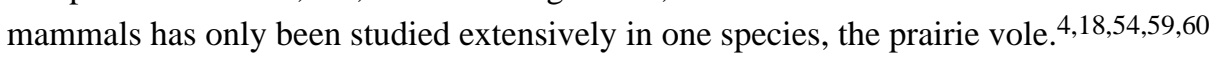
Specifically, prairie voles have been used to examine the formation of the "pair bond", which is the social bond formed between males and females of a species that often implies social monogamy. ${ }^{61}$

\section{The Pair Bond}

Prairie voles live in extended family groups and are considered as ocially monogamous species. ${ }^{62}$ The pair bond is defined as a preference for contact with a familiar sexual partner, selective aggression towards unfamiliar conspecifics, biparental care, socially regulated reproduction and incest avoidance. ${ }^{61,62}$ The formation of a pair bond is experimentally tested in the laboratory using a partner-preference test. ${ }^{63}$ In this behavioral test, a male and female are paired and allowed to cohabitate. To test for the pair bond, one of the "partner" individuals is tethered to one side of a three-chambered apparatus. A novel "stranger" animal is tethered to the opposing chamber. The subject animal is permitted to explore the three chambers freely and the amount of time the subject animal spends in proximity to, or huddling with, the "partner" versus "stranger" animal is recorded over a 3-hour testing period. If the subject spends twice as much time with the "partner" animal then it is said to have formed a pair bond with that individual. ${ }^{61,62,64,65}$

Due to the diversity in social structures within the genus Microtus, comparative studies between vole species has provided significant insight into the neural regulation of social bonding. By comparing the neurochemistry of monogamous vole species, such as the prairie or pine vole (Microtus pinetorum), to nonmonogamous voles, such as the montane (Microtus montanus) or meadow (Microtus pennsylvanicus) voles, scientists have had the opportunity to explore how variations in neurochemistry between highly related species can result in significant differences in social behavior. Differences in the Oxt and Avp systems between vole species has been found to contribute to their social organization. ${ }^{18,60}$

While there are not marked differences in Oxt and Avp immunopositive cells, or their projections, between species, there are changes in the distribution of the receptors for Oxt and Avp. Relative to nonmonogamous voles, monogamous voles have higher densities of Oxtr, as measured using Oxtr autoradiography and ISHH, in the NAcc, prefrontal cortex 
(PFC) and the BNST. Promiscuous voles, on the other hand, have higher Oxtr density in the LS, VMH and the cortical nucleus of the amygdala. ${ }^{66-68}$ Evidence that the differences in the distribution of the Oxtr between species might be behaviorally meaningful comes primarily from pharmacological studies.

In female prairie voles, central infusion of an Oxtr antagonist blocks the formation of the pair bond but has no effect on sexual behavior, whereas central infusion of Oxt facilitates the pair bond in the absence of mating. ${ }^{65,69,70}$ In the aforementioned studies the infusions were intracerebroventricular (icv), however manipulation of Oxtr signaling, using Oxtr antagonists within the NAcc, blocks formation of a partner preference following mating (Fig. 1). ${ }^{71,72}$ This finding is supported by a recent study in which Oxtr overexpressed in the NAcc of adult female prairie voles was found to accelerate the formation of partner preference. Interestingly, the same result was not found when the Oxtr was overexpressed in the nonmonogamous meadow vole, suggesting that in a nonmonogamous species Oxtr expression within the NAcc is not sufficient to promote pair bond formation. ${ }^{73}$

There are also differences in the distribution of the Avpr1a between vole species. Prairie voles have a higher density of Avprla, as measured using receptor autoradiography and ISHH, within the MeA, accessory olfactory bulb, diagonal band, thalamus, ventral pallidum (VP) and BNST compared to montane voles. ${ }^{74,75}$ Montane voles, on the other hand, have a higher density of Avpr1a in the medial PFC and the LS. ${ }^{68,75}$ These differing "patterns" of Avpr1a distribution have been suggested to underlie differences in social organization between monogamous and nonmonogamous vole species. This hypothesis has been confirmed, in part, by data in pine voles and meadow voles which suggest similar, social structure-specific distributions of Avprla between these species. ${ }^{75}$ Further support for this hypothesis comes from pharmacological manipulations of the Avpr1a in prairie voles. When an Avp antagonist is injected icv prior to mating, the formation of a partner preference is inhibited. Conversely, Avp infusion facilitates the formation of the partner preference. ${ }^{70,76}$ Some of the more interesting data that supports a role for the differential distribution of the Avpr1a in the formation of social bonds comes from a study in which the prairie vole Avprla gene was overexpressed in the ventral forebrain of meadow voles, resulting in increases in the amount of time meadow voles spent huddled with their partners compared to controls. ${ }^{77}$

It has been suggested that the differences in Avpr1a distribution between species are due to changes in the regulatory region upstream of the Avpr1a promoter. ${ }^{78-80}$ This idea is based on work demonstrating that changes in Avpr1a density within and between species can alter social behavior. ${ }^{77,81,82}$ Hammock and colleagues ${ }^{83,84}$ suggest that the presence or absence of a microsatellite sequence (i.e., simple sequence repeats with nonrepetitive elements) in the $5^{\prime}$ cis-regulatory region of the Avprla gene could be responsible for differences in Avpr1a density. To test this, two breeding lines of prairie voles were generated that had differing lengths of microsatellite sequence in the $5^{\prime}$ cis-regulatory region of the Avpr1a gene. The two breeding lines showed regional differences in the density of the Avpr1a and the breeding line with the longer microsatellite sequence tending to show more partner preference than the breeding line with the shorter microsatellite sequence. ${ }^{83}$ However, in a study that examined individual differences in Avpr1a expression in prairie voles housed in a 
semi-natural setting, Avprla expression in the VP or LS was found to not be predictive of social or sexual fidelity. Rather, differences in Avpr1a expression in brain areas with spatial memory were correlated with social and sexual fidelity. ${ }^{85}$ Further, differences in microsatellite length in field tests of prairie voles, while associated with Avpr1a density in brain areas associated important for pair bond formation, are not associated with differences in measures of monogamous behavior and reproductive success. ${ }^{86}$ Taken together, these data suggest that there are a variety of social and neurobiological factors that likely contribute to the formation of the partner preference and that changes in single gene are not sufficient to determine whether an animal is monogamous or polygamous.

\section{Aggressive Behavior}

Aggression is used by a variety of animals to develop and maintain social hierarchies, gain access to mates, protect young and defend territories. The ability to display aggression in the correct social context is critical for the survival and reproductive success of many species. Males are typically more aggressive than females, however, during pregnancy and in the postpartum period, there is often a rise in female aggression. ${ }^{87,88}$ Our understanding of the neural regulation of aggressive behavior is fairly limited in primates, but in rodents, pharmacological tools coupled with transgenic mouse models have substantially contributed to our understanding of the neural regulation of aggression.

In rodents, the most common assessment of aggression, specifically offensive aggression, uses the resident-intruder test. Subject "resident" animals are singly housed for several weeks prior to testing; in mice this results in an increase in baseline aggression due to isolation-induced aggression. An "intruder" animal, often smaller and group housed, is then placed into the cage of the resident animal. The latency to the onset of aggression as well as the frequency and duration of aggression are common behavioral measures. To test maternal aggression a similar test is employed, only the "resident" is a postpartum female with her pups in or removed from the cage.

The role of Oxt in the neural regulation of aggression has not been examined in much depth. Though, it does appear that in females Oxt reduces nonmaternal aggression in some species and facilitates maternal aggression in others. In female Syrian hamsters (Mesocricetus auratus), for instance, which are more aggressive than males of the species, there is evidence that a microinjection of Oxt into the medial preoptic area-anterior hypothalamus (MPOA-AH) reduces aggression directed toward a female intruder, ${ }^{89}$ but microinjections of Oxt, as well as Oxt antagonists, into the amygdala facilitate maternal aggression. ${ }^{90,91}$ Female prairie voles that receive Oxt icv have decreases in male-directed aggression ${ }^{92}$ and in rats, displays of maternal aggression can be facilitated by infusing Oxt into the amygdala ${ }^{91}$ and reduced by lesioning or infusing Oxt antisense oligonucleotides into the PVN. ${ }^{93,94}$ While there are mice in which Oxt and the Oxtr have been genetically disrupted, $\mathrm{Oxt}^{-/-}$and $\mathrm{Oxtr}^{-/-}$mice, respectively there are no reports of altered maternal aggression in these animals. ${ }^{95,96}$ Overall, the actions of Oxt in the regulation of aggression in females appears to be context specific and possibly species specific.

There have been very few reports supporting a role for Oxt in the regulation of aggression in males. Studies in $\mathrm{Oxt}^{-/-}$mice are conflicting, with one group reporting increases in 
aggressive behavior ${ }^{97}$ and another group reporting decreases in aggressive behavior. ${ }^{98,99}$ It should be noted, though, that the $\mathrm{Oxt}^{-/-}$mice tested were generated by two different groups and that the increases in aggressive behavior were only found in mice that were the offspring of null mutant parents; suggesting that Oxt exposure in the prenatal environment may be important to normal displays of aggression. This possibility is supported by a report of heightened aggression in $\mathrm{Oxtr}^{-/-}$male mice compared to controls when tested in a residentintruder behavioral test. ${ }^{96}$

Much of the work implicating Avp in the neural regulation of aggression has been completed in Syrian hamsters. As Syrian hamsters are a solitary species, they readily display aggression towards conspecifics. Further, they engage in a stereotypic type of scent marking behavior, referred to as flank marking, that is expressed at higher levels in socially dominant animals. ${ }^{100}$ Ferris and colleagues made the serendipitous discovery that Avp injected into the MPOA-AH results in a dose-dependent increase in flank marking behavior. ${ }^{101}$ This finding was one of the first to demonstrate that microinjection of a single neuropeptide into a specific brain region could induce a complex behavior. Avp injected into the anterior hypothalamus (AH) or ventral lateral hypothalamus (VLH) of Syrian hamsters has been found to facilitate aggressive behavior. ${ }^{7,102,103}$ Conversely, Avp antagonists and more specifically Avpr1a antagonists, injected into the AH inhibit aggression. ${ }^{102}$ The Avpr1b may also be important to the modulation of aggressive behavior in hamsters, as treatment with an oral Avpr $1 \mathrm{~b}$ antagonist results in decreases in aggressive behavior compared to controls. ${ }^{104}$ It has been suggested that the neural circuit that regulates aggression in Syrian hamsters includes the $\mathrm{AH}$, which has reciprocal connections with the VLH, the MeA and the BNST. ${ }^{105,106}$

Syrian hamsters exposed to anabolic-androgenic steroids during adolescence for at least 14 days display increased aggression in adulthood. They also have increases in Avpr-ir within the $\mathrm{AH}$ and injections of an Avpr1a antagonist in the $\mathrm{AH}$ reduces the intensity but not the onset of aggression. ${ }^{107-110}$ There are also reports of changes in social status affecting the Avp system in hamsters. Injections of an Avp antagonist into the MPOA-AH of a dominant hamster can transiently reverse dominant/subordinate relationships, as measured by flank marking ${ }^{111}$ Subordinate hamsters have fewer Avp-ir cell bodies in the nucleus circularis, a structure that is found within the AH, compared to dominant hamsters. ${ }^{112}$ In hamsters that are repeatedly defeated, there are coincident decreases in Avprla receptor binding within lateral portions of the VMH. ${ }^{113}$ Similarly, in hamsters that are singly housed for several weeks and not allowed to interact with other animals, there are increases in Avprla binding in the AH, PVN and lateral hypothalamus, whereas socially experienced hamsters have increased Avprla binding within the CeA. ${ }^{114}$ Even when Avp is used to facilitate aggression, social isolation for some period of time seems to be required. ${ }^{7,106}$ These data suggest that, at least in hamsters, the role of Avp in the regulation of aggression can be altered by social experience.

The modulation of aggression in rats and mice is due in part to gonadal steroid-dependent Avp projections from the BNST and the MeA to the LS. ${ }^{115-117}$ With the LS likely regulating the emotional aspects of aggression. ${ }^{18,119}$ Injections of Avp into the LS of rats and prairie voles can facilitate agonistic behavior. ${ }^{76,120,121}$ In sexually naïve males, Avp 
injected into the $\mathrm{AH}$, or overexpression of the prairie vole Avpr1a within the $\mathrm{AH}$, results in increases in selective aggression (i.e., aggression directed towards novel male or female animals). ${ }^{122}$ In mice selectively bred for either a long attack latency (LAL) or short attack latency (SAL), there is evidence of changes in Avp neurochemistry. SAL mice have fewer Avp-ir neurons in the BNST and fewer Avp-ir fibers in the LS compared to LAL mice suggesting that, within a species, less Avp within the LS may be associated with increased aggression. ${ }^{123}$ However, monogamous California mice (Peromyscus californicus) have shorter attack latencies and increased Avp-ir in the BNST and LS compared the polygamous, white-footed mice (Peromyscus leuориs). ${ }^{124}$ Interestingly, when California mice are cross-fostered to white-footed mice dams, they are less aggressive in adulthood than those reared by the same species and they have less Avp-ir in the BNST and SON compared to controls. ${ }^{125}$ The data in Peromyscus mice suggest that, similar to what has been found in hamsters, changes in the environment, in this case changes in the early postnatal period, are able to alter the Avp neurocircuity and subsequent behavior.

When mice with a genetic disruption of their Avprla were engineered, it was thought that they would provide some valuable insight into the role of the Avprla in the regulation of aggression. Surprisingly, Avprla knockout mice do not differ from wildtype controls in measures of aggression. ${ }^{126}$ It may be that the lack of aggressive phenotype in these mice is due to developmental compensation. Mice with a disruption of the Avprlb (Avpr1b ${ }^{-/-}$ mice), on the other hand, have implicated the Avprlb in the regulation of aggressive behavior. Avpr $1 b^{-/}$mice have marked reductions of forms of "social" aggression (i.e., those forms of aggression that require the animal to interact with a conspecific), such as those measured in resident-intruder, neutral arena and maternal aggression tests and no change in predatory aggression. ${ }^{127-129}$ When attacked, Avpr $1 b^{-/-}$mice will defend themselves but will initiate fewer "retaliatory" attacks compared to wildtype controls. ${ }^{128}$ Even Avpr1b $\mathrm{b}^{-/}$mice that are crossed with a more outbred substrain of mice, Mus musculus castaneous, continue to have reduced aggression (Fig. 2). ${ }^{130}$ Since the distribution of the Avpr $1 \mathrm{~b}$ in the mouse brain is fairly restricted, with prominence in the CA2 field of the hippocampus, it has been proposed that it may be important to the formation or recall of memories that have an accessory olfactory-based component. ${ }^{52,127}$

\section{SOCIABILITY IN HUMANS}

In humans there is evidence that Oxt promotes prosocial behavior. The study of prosocial behavior in humans includes testing procedures designed to measure trust, the ability to read facial expressions and the memory for socially salient information, such as faces. In most of the studies in humans, Oxt has been administered intranasally, as Oxt is thought to be able to cross the blood brain barrier using this route of delivery. ${ }^{131}$ Intranasal administration of Oxt results in an increase in trust in humans, as measured by an individual's willingness to accept social risk during a social interaction. ${ }^{132}$ Further, when intranasal Oxt treatment is coupled with functional magnetic resonance imaging, there is a reduction in activity in areas of the brain associated with processing fearful stimuli, such as the amygdala and some areas of the midbrain and reward feedback, such as the striatum. In individuals administered Oxt intranasally, betrayal of trust results in no change in trust behavior, whereas placebo controls decrease their trust in response to betrayal. ${ }^{133}$ These data suggest that Oxt acting as an 
anxiolytic and stress-reducer is allowing for higher levels of sociability. There is also evidence that intranasal Oxt improves the ability to infer another individual's mental state, improves facial recognition memory and alters the processing of faces. ${ }^{134-138}$

The role of vasopressin in the regulation of social behavior in humans has not been studied as extensively as Oxt, though it is often associated with antisocial rather than prosocial behavior. In males, Avp administered intranasally results in increases in electromyogram (EMG) activity to socially neutral facial expressions. This suggests that Avp acts to bias an individual to perceive a neutral stimulus as an aggressive or threatening stimulus. ${ }^{139}$ When administered to females, Avp decreases EMG responses to happy and angry faces, suggesting that in females, Avp acts to increase the perception of friendliness. ${ }^{140}$ The researchers that conducted the aforementioned work suggest that the differential actions of Avp between men and women reflect differences in social strategies during socially stressful interactions.

\section{Neuropsychiatric Disorders}

Oxt and Avp have also been implicated in a variety of neuropsychiatric disorders, particularly those that are characterized by alterations in social interactions or heightened aggression, such as: Autism spectrum disorders (ASD), personality disorder and schizophrenia. In this section the contributions of Oxt and Avp to neuropsychiatric disorders will be briefly reviewed.

\section{Autism Spectrum Disorders}

ASD are characterized by repetitive behaviors, communication difficulties and abnormal sociability. ${ }^{141,142}$ One of the reasons Oxt has been suggested to contribute to ASD is that in mice that lack Oxt, or Oxtr, there are behavioral deficits that are consistent with some of the symptoms of ASD. ${ }^{95,143-149}$ Evidence that Oxt may have a role in ASD comes from several sources. There are reports of lower Oxt in the CSF of autistic children and reduced Oxtis correlated with impairments in social functioning. ${ }^{150}$ There are also increases in the amount of an Oxt prohormone in the blood of autistic children, which is indicative of incomplete processing of Oxt into its biologically active form. ${ }^{151}$ Oxt treatment in adults with ASD results in the reduction of repetitive behaviors and improvements in emotional recognition. ${ }^{152,153}$ Some genetic and epigenetic links between the Oxtsystem and ASD have also started to emerge. There are data in the Chinese Han population, Finnish families, Caucasian children and in individuals with "high-functioning" ASD suggesting that portions of the Oxtr gene may contain susceptibility loci for ASD. ${ }^{154-157}$ Epigenetic modifications of the Oxtr gene have also been reported, with hypermethylation of the Oxtr promoter found in autistic subjects and subsequent reductions in Oxtr mRNA. ${ }^{158}$ Though the sample size in the aforementioned study is small, the data are provocative and will likely facilitate more research in this area.

Data implicating Avp in the etiology of ASD are sparse, but there have been studies suggesting that polymorphisms of the Avpr1a may contribute to ASD. ${ }^{159-161}$ Further, two of the polymorphisms, RS3 and RS1, have been linked to differential activation in the 
amygdala, ${ }^{162}$ providing a possible neural substrate with which the Avp system may interact to mediate a genetic risk for ASD.

\section{Personality Disorder}

Personality disorder is characterized by a disconnect between an individual's behavior and cultural norms. Those diagnosed with personality disorder have impairments in at least two of the following areas: (1) cognition, (2) affectivity, (3) interpersonal functioning and (4) impulse control. ${ }^{163}$ To date, only one study has examined changes in Oxt between individuals diagnosed with a personality disorder and healthy controls. This study found that while having a personality disorder was not correlated with cerebral spinal fluid Oxt, a life history of suicidal behavior was inversely correlated with Oxt. ${ }^{164}$ The authors suggest that these data are consistent with the previous work in animal models which suggest that Oxt reduces aggression. $89,92-94$

Since individuals with a personality disorder are often more impulsive, which can result in increased aggression, it is not surprising that Avp has been examined in these individuals. Unfortunately, the data appear to be contradictory. A study by Coccaro and colleagues ${ }^{165}$ found a positive correlation between Avp in the CSF of personality-disordered individuals that have a life history of aggressive behavior. Whereas another study found no differences in CSF Avp between violent offenders and controls. ${ }^{166}$ It may be that differences in the populations studied account for the inconsistency in the findings, but it seems that more work in this area is warranted.

\section{Schizophrenia}

There are three broad categories of symptoms that characterize schizophrenia: (1) positive (e.g., hallucinations and delusion), (2) negative (e.g., anhedonia, impaired social behavior), (3) cognitive/attentional (e.g., impaired memory and executive function). Thus far, most of the work implicating a role for Oxt in aspects of schizophrenia comes from animal models. ${ }^{167-169}$ However, in humans, while its role has remained controversial, Oxt has been linked to schizophrenia since the1970's when it was used a sanantipsychotic. ${ }^{170,171}$ The data are mixed with regards to Oxt and schizophrenic populations, with one study reporting increases in plasma Oxt concentrations, ${ }^{172}$ another study reporting no change,,${ }^{173}$ and a third reporting decreases. ${ }^{174}$ Though, similar to measures of Avp in individuals with personality disorder, these discrepancies may reflect differences in the populations of those that were studied.

Support for a potential role for Avp comes from studies indicating that treatment with neuroleptics improves psychiatric symptoms and reduces (or normalizes) Avp in blood plasma. ${ }^{175,176}$ In studies using an animal model that lacks Avp, the Brattleboro rat, there are reports of deficits in behaviors associated with schizophrenia, specifically, social discrimination and prepulse inhibition of the startle reflex; these deficits can be rescued following treatment with antipsychotics. ${ }^{177-181}$ It may be that Oxt and Avp only contribute to certain aspects of schizophrenia, such as the cognitive and social behavior deficits, within specific populations. Since treatment with antipsychotics often does not significantly 
improve the cognitive and negative symptoms associated with schizophrenia, it is important continue to investigate the neurobiology that underlies these behaviors.

\section{CONCLUSION AND FUTURE DIRECTIONS}

This is an exciting time for the neurobiology of sociability. The roles of Oxt and Avp are being explored and a more complete understanding of how these neurohormones interact with other neurotransmitter and neurohormone systems, such as dopamine and corticotropin releasing factor, are beginning to emerge. ${ }^{71,182-188}$ There is diversity in the animal models being used, ranging from comparative studies to transgenic studies, that have revealed remarkable conservation in the roles of Oxt and Avp across species. Research examining sociability in humans is on the rise and with the use of pharmacological, genetic and imaging tools the link between the animal models of sociability and human behavior is becoming less tenuous. Further, in human neuropsychiatric disorders characterized by impaired sociability, the roles of Oxt and Avp are being elucidated and better pharmacological agents are being developed. ${ }^{189-192}$

\section{Acknowledgments}

The author would like to thank Drs., Abbe Macbeth, Colleen Novak and W. Scott Young, III for comments on the manuscript. The author is currently supported by NIH MH083963.

\section{References}

1. Pinkham AE, Penn DL, Perkins DO, et al. Implications for the neural basis of social cognition for the study of schizophrenia. Am J Psychiatry. 2003; 160(5):815-824. [PubMed: 12727681]

2. Hill EL, Frith U. Understanding autism: insights from mind and brain. Philos Trans R Soc Lond B Biol Sci. 2003; 358(1430):281-289. [PubMed: 12639326]

3. Hammock EA, Young LJ. Oxytocin, vasopressin and pair bonding: implications for autism. Philos Trans R Soc Lond B Biol Sci. 2006; 361(1476):2187-2198. [PubMed: 17118932]

4. Lim MM, Young LJ. Neuropeptidergic regulation of affiliative behavior and social bonding in animals. Horm Behav. 2006; 50(4):506-517. [PubMed: 16890230]

5. McCarthy MM, Wright CL, Schwarz JM. New tricks by an old dogma: mechanisms of the organizational/activational hypothesis of steroid-mediated sexual differentiation of brain and behavior. Horm Behav. 2009; 55(5):655-665. [PubMed: 19682425]

6. Berthold AA. Transplantation der Hoden. Arch Ant Physiol Wissenschr Med. 1849:42-46.

7. Caldwell HK, Albers HE. Effect of photoperiod on vasopressin-induced aggression in Syrian hamsters. Horm Behav. 2004; 46(4):444-449. [PubMed: 15465530]

8. Jasnow AM, Huhman KL, Bartness TJ, et al. Short days and exogenous melatonin increase aggression of male Syrian hamsters (Mesocricetus auratus). Horm Behav. 2002; 42:13-20. [PubMed: 12191643]

9. Elliott AS, Nunez AA. Photoperiod modulates the effects of steroids on sociosexual behaviors of hamsters. Physiol Behav. 1992; 51:1189-1193. [PubMed: 1641420]

10. Demas GE, Polacek KM, Durazzo A, et al. Adrenal hormones mediate melatonin-induced increases in aggression in male Siberian hamsters (Phodopus sungorus). Horm Behav. 2004; 46(5): 582-591. [PubMed: 15555500]

11. Jasnow AM, Huhman KL, Bartness TJ, et al. Short-day increases in aggression are inversely related to circulating testosterone concentrations in male siberian hamsters (Phodopus sungorus). Horm Behav. 2000; 38:102-110. [PubMed: 10964524]

12. Acher R, Chauvet J. The neurohypophysial endocrine regulatory cascade: precursors, mediators, receptors and effectors. Front Neuroendocrinol. 1995; 16(3):237-289. [PubMed: 7556852] 
13. Acher R, Chauvet J, Chauvet MT. Man and chimera: selective versus neutral oxytocin evolution. Adv Exp Med Biol. 1995; 395:615-627. [PubMed: 8714026]

14. Hara Y, Battey J, Gainer H. Structure of mouse vasopressin and oxytocin genes. Brain Res Mol Brain Res. 1990; 8:319-324. [PubMed: 2176709]

15. Caldwell HK, Lee HJ, Macbeth AH, et al. Vasopressin: behavioral roles of an "original" neuropeptide. Prog Neurobiol. 2008; 84(1):1-24. [PubMed: 18053631]

16. Caldwell, HK.; Young, WS., 3rd; Lim, R. Oxytocin and vasopressin: genetics and behavioral implications. In: Lajtha, A., editor. Neuroactive Proteins and Peptides. Vol. 3. New York: Springer; 2006. p. 573-607.

17. Lee HJ, Macbeth AH, Pagani JH, et al. Oxytocin: the great facilitator of life. Prog Neurobiol. 2009; 88(2):127-151. [PubMed: 19482229]

18. Adkins-Regan E. Neuroendocrinology of social behavior. ILAR J. 2009; 50(1):5-14. [PubMed: 19106448]

19. Neumann ID. Brain oxytocin: a key regulator of emotional and social behaviours in both females and males. J Neuroendocrinol. 2008; 20(6):858-865. [PubMed: 18601710]

20. Veenema AH, Neumann ID. Central vasopressin and oxytocin release: regulation of complex social behaviours. Prog Brain Res. 2008; 170:261-276. [PubMed: 18655888]

21. Carter CS, Grippo AJ, Pournajafi-Nazarloo H, et al. Oxytocin, vasopressin and sociality. Prog Brain Res. 2008; 170:331-336. [PubMed: 18655893]

22. Dale HH. On some physiological actions of ergot. J Physiol (Lond). 1906; 34:163-206. [PubMed: 16992821]

23. Ott I, Scott JC. The action of infundibulin upon the mammary secretion. Proc Soc Exp Biol Med. $1910 ; 8: 48-49$.

24. Castel M, Morris JF. The neurophysin-containing innervation of the forebrain of the mouse. Neuroscience. 1988; 24(3):937-966. [PubMed: 3380308]

25. Jirikowski GF, Caldwell JD, Stumpf WE, et al. Topography of oxytocinergic estradiol target neurons in the mouse hypothalamus. Folia Histochem Cytobiol. 1990; 28:3-9. [PubMed: 2097180]

26. Wang Z, Zhou L, Hulihan TJ, et al. Immunoreactivity of central vasopressin and oxytocin pathways in microtine rodents: a quantitative comparative study. J Comp Neurol. 1996; 366(4): 726-737. [PubMed: 8833119]

27. Ross HE, Cole CD, Smith Y, et al. Characterization of the oxytocin system regulating affiliative behavior in female prairie voles. Neuroscience. 2009; 162(4):892-903. [PubMed: 19482070]

28. Kimura T, Tanizawa O, Mori K, et al. Structure and expression of a human oxytocin receptor. Nature. 1992; 356:526-529. [PubMed: 1313946]

29. Kubota Y, Kimura T, Hashimoto K, et al. Structure and expression of the mouse oxytocin receptor gene. Mol Cell Endocrinol. 1996; 124(1-2):25-32. [PubMed: 9027321]

30. Gimpl G, Fahrenholz F. The oxytocin receptor system: structure, function and regulation. Physiol Rev. 2001; 81(2):629-683. [PubMed: 11274341]

31. Kremarik P, Freund-Mercier MJ, Stoeckel ME. Histoautoradiographic detection of oxytocin- and vasopressin-binding sites in the telencephalon of the rat. J Comp Neurol. 1993; 333(3):343-359. [PubMed: 8394391]

32. Veinante P, Freund-Mercier MJ. Distribution of oxytocin- and vasopressin-binding sites in the rat extended amygdala: a histoautoradiographic study. J Comp Neurol. 1997; 383(3):305-325. [PubMed: 9205043]

33. Insel TR, Gelhard R, Shapiro LE. The comparative distribution of forebrain receptors for neurohypophyseal peptides in monogamous and polygamous mice. Neuroscience. 1991; 43(2-3): 623-630. [PubMed: 1656322]

34. Sofroniew MV. Morphology of vasopressin and oxytocin neurones and their central and vascular projections. Prog Brain Res. 1983; 60:101-114. [PubMed: 6198686]

35. Sofroniew MV. Vasopressin-and neurophysin-immunoreactive neurons in the septal region, medial amygdala and locus coeruleus in colchicine-treated rats. Neuroscience. 1985; 15(2):347-358. [PubMed: 4022328] 
36. Buijs RM, De Vries GJ, Van Leeuwen FW, et al. Vasopressin and oxytocin: distribution and putative functions in the brain. Prog Brain Res. 1983; 60:115-122. [PubMed: 6665132]

37. Buijs, RM.; Gash, DM.; Boer, GJ. Vasopressin: Principles and Properties. New York: Plenum Press; 1987. Vasopressin localization and putative functions in the brain; p. 91-115.

38. De Vries GJ, Buijs RM. The origin of the vasopressinergic and oxytocinergic innervation of the rat brain with special reference to the lateral septum. Brain Res. 1983; 273(2):307-317. [PubMed: 6311351]

39. Sawchenko PE, Swanson LW. Immunohistochemical identification of neurons in the paraventricular nucleus of the hypothalamus that project to the medulla or to the spinal cord in the rat. J Comp Neurol. 1982; 205(3):260-272. [PubMed: 6122696]

40. Ostrowski NL, Lolait SJ, Bradley DJ, et al. Distribution of V1a and V2 vasopressin receptor messenger ribonucleic acids in rat liver, kidney, pituitary and brain. Endocrinology. 1992; 131(1): 533-535. [PubMed: 1535312]

41. Watters JJ, Poulin P, Dorsa DM. Steroid homone regulation of vasopressinergic neurotransmission in the central nervous system. Prog Brain Res. 1998; 119:247-261. [PubMed: 10074792]

42. Johnson AE, Barberis C, Albers HE. Castration reduces vasopressin receptor binding in the hamster hypothalamus. Brain Res. 1995; 674:153-158. [PubMed: 7773686]

43. Tribollet E, Barberis C, Arsenijevic Y. Distribution of vasopressin and oxytocin receptors in the rat spinal cord: sex-related differences and effect of castration in pudendal motor nuclei. Neuroscience. 1997; 78(2):499-509. [PubMed: 9145805]

44. Ostrowski NL, Lolait SJ, Young WS. Cellular localization of vasopressin V1a receptor messenger ribonucleic acid in adult male rat brain, pineal and brain vasculature. Endocrinology. 1994; 135(4): 1511-1528. [PubMed: 7925112]

45. Szot P, Bale TL, Dorsa DM. Distribution of messenger RNA for the vasopressin V1a receptor in the CNS of male and female rats. Brain Res Mol Brain Res. 1994; 24(1-4):1-10. [PubMed: 7968346]

46. Antoni FA. Novel ligand specificity of pituitary vasopressin receptors in the rat. Neuroendocrinology. 1984; 39:186-188. [PubMed: 6089020]

47. Lolait SJ, O'Carroll AM, Mahan LC, et al. Extrapituitary expression of the rat V1b vasopressin receptor gene. Proc Natl Acad Sci USA. 1995; 92(15):6783-6787. [PubMed: 7624319]

48. Saito M, Sugimoto T, Tahara A, et al. Molecular cloning and characterization of rat V1b vasopressin receptor: evidence for its expression in extra-pituitary tissues. Biochem Biophys Res Commun. 1995; 212:751-757. [PubMed: 7626108]

49. Vaccari C, Lolait SJ, Ostrowski NL. Comparative distribution of vasopressin V1b and oxytocin receptor messenger ribonucleic acids in brain. Endocrinology. 1998; 139:5015-5033. [PubMed: 9832441]

50. Hernando F, Schoots O, Lolait SJ, et al. Immunohistochemical localization of the vasopressin V1b receptor in the rat brain and pituitary gland: anatomical support for its involvement in the central effects of vasopressin. Endocrinology. 2001; 142(4):1659-1668. [PubMed: 11250948]

51. Stemmelin J, Lukovic L, Salome N, et al. Evidence that the lateral septum is involved in the antidepressant like effects of the vasopressin V (1b) receptor antagonist SSR149415. Neuropsychopharmacology. 2005; 30:35-42. [PubMed: 15367924]

52. Young WS, Li J, Wersinger SR, et al. The vasopressin $1 \mathrm{~b}$ receptor is prominent in the hippocampal area CA2 where it is unaffected by restraint stress or adrenalectomy. Neuroscience. 2006; 143(4): 1031-1039. [PubMed: 17027167]

53. Bankir L. Antidiuretic action of vasopressin: quantitative aspects and interaction between V1a and V2 receptor-mediated effects. Cardiovasc Res. 2001; 51(3):372-390. [PubMed: 11476728]

54. Carter CS. Neuroendocrine perspectives on social attachment and love. Psychoneuroendocrinology. 1998; 23(8):779-818. [PubMed: 9924738]

55. Uvnas-Moberg K. Physiological and endocrine effects of social contact. Ann N Y Acad Sci. 1997; 807:146-163. [PubMed: 9071348]

56. Silk JB. The adaptive value of sociality in mammalian groups. Philos Trans R Soc Lond B Biol Sci. 2007; 362(1480):539-559. [PubMed: 17363359] 
57. Silk JB, Beehner JC, Bergman TJ, et al. The benefitsof social capital: close social bonds among female baboons enhance offspring survival. Proc Biol Sci. 2009; 276(1670):3099-3104. [PubMed: $19515668]$

58. Cameron EZ, Setsaas TH, Linklater WL. Social bonds between unrelated females increase reproductive success in feral horses. Proc Natl Acad Sci USA. 2009; 106(33):13850-13853. [PubMed: 19667179]

59. Insel TR. A neurobiological basis of social attachment. Am J Psychiatry. 1997; 154(6):726-735. [PubMed: 9167498]

60. Young KA, Liu Y, Wang Z. The neurobiology of social attachment: a comparative approach to behavioral, neuroanatomical and neurochemical studies. Comp Biochem Physiol C Toxicol Pharmacol. 2008; 148(4):401-410. [PubMed: 18417423]

61. Carter CS, Getz LL. Monogamy and the prairie vole. Sci Am. 1993; 268(6):100-106. [PubMed: 8516669]

62. Carter CS, DeVries AC, Getz LL. Physiological substrates of mammalian monogamy: the prairie vole model. Neurosci Biobehav Rev. 1995; 19(2):303-314. [PubMed: 7630584]

63. Williams JR, Catania KC, Carter CS. Development of partner preferences in female prairie voles (Microtus ochrogaster): the role of social and sexual experience. Horm Behav. 1992; 26(3):339349. [PubMed: 1398553]

64. Insel TR, Hulihan TA. A gender-specific mechanism for pair bonding: oxytocin and partner preference formation in monogamous voles. Behav Neurosci. 1995; 109:782-789. [PubMed: 7576222]

65. Williams JR, Insel TR, Harbaugh CR, et al. Oxytocin administered centrally facilitates formation of a partner preference in prairie voles (Microtus ochrogaster). J Neuroendocrinol. 1994; 6:247250. [PubMed: 7920590]

66. Insel TR, Shapiro LE. Oxytocin receptor distribution relects social organization in monogamous and polygamous voles. Proc Natl Acad Sci USA. 1992; 89:5981-5985. [PubMed: 1321430]

67. Young LJ, Huot B, Nilsen R, et al. Species differences in central oxytocin receptor gene expression: comparative analysis of promoter sequences. J Neuroendocrinol. 1996; 8(10):777-783. [PubMed: 8910808]

68. Smeltzer MD, Curtis JT, Aragona BJ, et al. Dopamine, oxytocin and vasopressin receptor binding in the medial prefrontal cortex of monogamous and promiscuous voles. Neurosci Lett. 2006; 394(2):146-151. [PubMed: 16289323]

69. Insel TR, Winslow JT, Wang ZX, et al. Oxytocin and the molecular basis of monogamy. Adv Exp Med Biol. 1995; 395:227-234. [PubMed: 8713971]

70. Cho MM, DeVries AC, Williams JR, et al. The effects of oxytocin and vasopressin on partner preferences in male and female prairie voles (Microtus ochrogaster). Behav Neurosci. 1999; 113(1071):1079.

71. Liu Y, Wang ZX. Nucleus accumbens oxytocin and dopamine interact to regulate pair bond formation in female prairie voles. Neuroscience. 2003; 121:537-544. [PubMed: 14568015]

72. Young LJ, Lim MM, Gingrich B, et al. Cellular mechanisms of social attachment. Horm Behav. 2001; 40(2):133-138. [PubMed: 11534973]

73. Ross HE, Freeman SM, Spiegel LL, et al. Variation in oxytocin receptor density in the nucleus accumbens has differential effects on affiliative behaviors in monogamous and polygamous voles. J Neurosci. 2009; 29(5):1312-1318. [PubMed: 19193878]

74. Young LJ, Winslow JT, Nilsen R, et al. Species differences in V1a receptor gene expression in monogamous and nonmonogamous voles: behavioral consequences. Behav Neurosci. 1997; 111(3):599-605. [PubMed: 9189274]

75. Insel TR, Wang ZX, Ferris CF. Patterns of brain vasopressin receptor distribution associated with social organization in microtine rodents. J Neurosci. 1994; 14:5381-5392. [PubMed: 8083743]

76. Winslow JT, Hastings N, Carter CS, et al. A role for central vasopressin in pair bonding in monogamous prairie voles. Nature. 1993; 365:545-548. [PubMed: 8413608]

77. Lim MM, Wang Z, Olazabal DE, et al. Enhanced partner preference in a promiscuous species by manipulating the expression of a single gene. Nature. 2004; 429(6993):754-757. [PubMed: 15201909] 
78. Young LJ, Nilsen R, Waymire KG, et al. Increased affiliative response to vasopressin in mice expressing the V1a receptor from a monogamous vole. Nature. 1999; 400(6746):766-768. [PubMed: 10466725]

79. Lim MM, Hammock EA, Young LJ. The role of vasopressin in the genetic and neural regulation of monogamy. J Neuroendocrinol. 2004; 16(4):325-332. [PubMed: 15089970]

80. Hammock EA, Young LJ. Functional microsatellite polymorphism associated with divergent social structure in vole species. Mol Biol Evol. 2004; 21(6):1057-1063. [PubMed: 15014156]

81. Pitkow LJ, Sharer CA, Ren X, et al. Facilitation of affiliation and pair-bond formation by vasopressin receptor gene transfer into the ventral forebrain of a monogamous vole. J Neurosci. 2002; 21(18):7392-7396. [PubMed: 11549749]

82. Landgraf R, Frank E, Aldag JM, et al. Viral vector-mediated gene transfer of the vole V1a vasopressin receptor in the rat septum: improved social discrimination and active social behaviour. Eur J Neurosci. 2003; 18:403-411. [PubMed: 12887422]

83. Hammock EA, Young LJ. Microsatellite instability generates diversity in brain and sociobehavioral traits. Science. 2005; 308(5728):1630-1634. [PubMed: 15947188]

84. Hammock EAD, Lim MM, Young LJ. Microsatellite polymorphism predicts vasopressin 1a receptor gene expression and behavior in prairie voles. Society for Neuroscience. 2004:440-443.

85. Ophir AG, Wolff JO, Phelps SM. Variation in neural V1aR predicts sexual fidelity and space use among male prairie voles in semi-natural settings. Proc Natl Acad Sci USA. 2008; 105(4):12491254. [PubMed: 18212120]

86. Ophir AG, Campbell P, Hanna K, et al. Field tests of cis-regulatory variation at the prairie vole avpr1a locus: association with V1aR abundance but not sexual or social fidelity. Horm Behav. 2008; 54(5):694-702. [PubMed: 18722379]

87. Numan, M.; Insel, TR. The Neurobiology of Parental Care. New York: Springer-Verlag; 2003.

88. Svare, BB. Maternal aggression in mammals. In: Gubernick, DJ.; Klopfer, PH., editors. Parental Care in Mammals. New York: Plenum Press; 1981. p. 179-210.

89. Harmon AC, Huhman KL, Moore TO, et al. Oxytocin inhibits aggression in female Syrian hamsters. J Neuroendocrinol. 2002; 14(12):963-969. [PubMed: 12472877]

90. Ferris CF, Foote KB, Meltser HM, et al. Oxytocin in the amygdala facilitates maternal aggression. Ann NY Acad Sci. 1992; 652:456-457. [PubMed: 1626847]

91. Lubin DA, Elliott JC, Black MC, et al. An oxytocin antagonist infused into the central nucleus of the amygdala increases maternal aggressive behavior. Behav Neurosci. 2003; 117(2):195-201. [PubMed: 12708515]

92. Bales KL, Carter CS. Sex differences and developmental effects of oxytocin on aggression and social behavior in prairie voles (Microtus ochrogaster). Horm Behav. 2003; 44(3):178-184. [PubMed: 14609540]

93. Giovenardi M, Padoin MJ, Cadore LP, et al. Hypothalamic paraventricular nucleus modulates maternal aggression in rats: effects of ibotenic acid lesion and oxytocin antisense. Physiol Behav. 1998; 63(3):351-359. [PubMed: 9469726]

94. Consiglio AR, Lucion AB. Lesion of hypothalamic paraventricular nucleus and maternal aggressive behavior in female rats. Physiol Behav. 1996; 59(4-5):591-596. [PubMed: 8778839]

95. Lee HJ, Caldwell HK, Macbeth AH, et al. A conditional knockout mouse line of the oxytocin receptor. Endocrinology. 2008; 149(7):3256-3263. [PubMed: 18356275]

96. Takayanagi Y, Yoshida M, Bielsky IF, et al. Pervasive social deficits, but normal parturition, in oxytocin receptor-deficient mice. Proc Natl Acad Sci USA. 2005; 102(44):16096-16101. [PubMed: 16249339]

97. Winslow JT, Hearn EF, Ferguson J, et al. Infant vocalization, adult aggression and fear behavior in an oxytocin null mutant mouse. Horm Behav. 2000; 37:145-155. [PubMed: 10753584]

98. DeVries AC, Young WS III, Nelson RJ. Reduced aggressive behaviour in mice with targeted disruption of the oxytocin gene. J Neuroendocrinol. 1997; 9(5):363-368. [PubMed: 9181490]

99. Young WS, Shepard E, DeVries AC, et al. Targeted reduction of oxytocin expression provides insights into its physiological roles. Adv Exp Med Biol. 1998; 449:231-240. [PubMed: 10026810] 
100. Siegel, HI. The Hamster: Reproduction and Behavior. New York: Plenum Press; 1985. Aggressive behavior; p. 261-286.

101. Ferris CF, Albers HE, Wesolowski SM, et al. Vasopressin injected into the hypothalamus triggers a complex stereotypic behavior in golden hamsters. Science. 1984; 224:521-523. [PubMed: 6538700]

102. Ferris CF, Potegal M. Vasopressin receptor blockade in the anterior hypothalamus suppresses aggression in hamsters. Physiol Behav. 1988; 44:235-239. [PubMed: 2853382]

103. Delville Y, Mansour KM, Ferris CF. Testosterone facilitates aggression by modulating vasopressin receptors in the hypothalamus. Physiol Behav. 1996; 60(1):25-29. [PubMed: 8804638]

104. Blanchard RJ, Griebel G, Farrokhi C, et al. AVP V(1b) selective antagonist SSR149415 blocks aggressive behaviors in hamsters. Pharmacol Biochem Behav. 2005; 80(1):189-194. [PubMed: 15652395]

105. Albers, HE.; Huhman, KL.; Meisel, RL., et al. Hormones, Brain and Behavior. Amsterdam: Academic Press; 2002. Hormonal basis of social conflict and communication; p. 393-433.

106. Ferris CF, Melloni RH Jr, Koppel G, et al. Vasopressin/serotonin interactions in the anterior hypothalamus control aggressive behavior in golden hamsters. J Neurosci. 1997; 17(11):43314340. [PubMed: 9151749]

107. Grimes JM, Ricci LA, Melloni RH Jr. Plasticity in anterior hypothalamic vasopressin correlates with aggression during anabolic-androgenic steroid withdrawal in hamsters. Behav Neurosci. 2006; 120(1):115-124. [PubMed: 16492122]

108. Melloni RH Jr, Conner DF, Hang PTX, et al. Anabolic androgenic steroid exposure during adolescence and aggressive behavior in golden hamsters. Physiol Behav. 1997; 61:359-364. [PubMed: 9089753]

109. Harrison RJ, Connor DF, Nowak C, et al. Chronic anabolic androgenic steroid treatment during adolescence increases anterior hypothalamic vasopressin and aggression in intact hamsters. Psychoneuroendocrinology. 2000; 25(4):317-338. [PubMed: 10725610]

110. Grimes JM, Ricci LA, Melloni RH Jr. Alterations in anterior hypothalamic vasopressin, but not serotonin, correlate with the temporal onset of aggressive behavior during adolescent anabolicandrogenic steroid exposure in hamsters (Mesocricetus auratus). Behav Neurosci. 2007; 121(5): 941-948. [PubMed: 17907826]

111. Ferris CF, Meenan DM, Axelson JF, et al. A vasopressin antagonist can reverse dominant/ subordinate behavior in hamsters. Physiol Behav. 1986; 38:135-138. [PubMed: 3786493]

112. Ferris CF, Axelson JF, Martin AM, et al. Vasopressin immunoreactivity in the anterior hypothalamus is altered during the establishment of dominant/subordinate relationships between hamsters. Neuroscience. 1989; 29(3):675-683. [PubMed: 2739905]

113. Cooper MA, Karom M, Huhman KL, et al. Repeated agonistic encounters in hamsters modulate AVP V1a receptor binding. Horm Behav. 2005; 48(5):545-551. [PubMed: 15935353]

114. Albers HE, Dean A, Karom MC, et al. Role of V1a vasopressin receptors in the control of aggression in Syrian hamsters. Brain Res. 2006; 1073-1074:425-430.

115. De Vries GJ, Buijs RM, Swaab DF. The vasopressinergic innervation of the brain in normal and castrated rats. J Comp Neurol. 1985; 233:236-254. [PubMed: 3882778]

116. De Vries GJ, Wang Z, Bullock NA, et al. Sex differences in the effects of testosterone and its metabolites on vasopressin messenger RNA levels in the bed nucleus of the stria terminalis of rats. J Neurosci. 1994; 14:1789-1794. [PubMed: 8126571]

117. Van Leeuwen FW, Caffä SR, De Vries GJ. Vasopressin cells in the bed nucleus of the stria terminalis of the rat: sex differences and the influence of androgens. Brain Res. 1985; 325:391394. [PubMed: 3978433]

118. Desmedt A, Garcia R, Jaffard R. Vasopressin in the lateral septum promotes elemental conditioning to the detriment of contextual fear conditioning in mice. Eur J Neurosci. 1999; 11:3913-3921. [PubMed: 10583480]

119. Everts HGJ, Koolhaas JM. Differential modulation of lateral septal vasopressin receptor blockade in spatial learning, social recognition and anxiety-related behaviors in rats. Behav Brain Res. 1999; 99(1):7-16. [PubMed: 10512567] 
120. Koolhaas, JM.; Moor, E.; Hiemstra, Y., et al. The testosterone-dependent vasopressinergic neurons in the medial amygdala and lateral septum: involvement in social behaviour in male rats. Proceedings of the Third International Vasopressin Conference; Paris/London: Colloque INSERM/John Libbey Eurotext Ltd; 1991. p. 213-219.

121. Wang Z, Ferris CF, DeVries GJ. Role of septal vasopressin innervation in paternal behavior in prarie voles (Microtus ochrogaster). Proc Natl Acad Sci USA. 1994; 91:400-404. [PubMed: 8278401]

122. Gobrogge KL, Liu Y, Young LJ, et al. Anterior hypothalamic vasopressin regulates pair-bonding and drug-induced aggression in a monogamous rodent. Proc Natl Acad Sci USA. 2009; 106(45): 19144-19149. [PubMed: 19858480]

123. Compaan JC, Buijs RM, Pool CW, et al. Differential lateral septal vasopressin innervation in aggressive and nonaggressive male mice. Brain Res Bull. 1993; 30(1-2):1-6. [PubMed: 8420617]

124. Bester-Meredith JK, Young LJ, Marler CA. Species differences in paternal behavior and aggression in Peromyscus and their associations with vasopressin immunoreactivity and receptors. Horm Behav. 1999; 36:25-38. [PubMed: 10433884]

125. Bester-Meredith JK, Marler CA. Vasopressin and aggression in cross-fostered California mice (Peromyscus californicus) and white-footed mice (Peromyscus leucopus). Horm Behav. 2001; 40(1):51-64. [PubMed: 11467884]

126. Wersinger SR, Caldwell HK, Martinez L, et al. Vasopressin 1a receptor knockout mice have a subtle olfactory deficit but normal aggression. Genes Brain Behav. 2007; 6(6):540-551. [PubMed: 17083331]

127. Caldwell HK, Wersinger SR, Young WS 3rd. The role of the vasopressin $1 \mathrm{~b}$ receptor in aggression and other social behaviours. Prog Brain Res. 2008; 170:65-72. [PubMed: 18655872]

128. Wersinger SR, Caldwell HK, Christiansen M, et al. Disruption of the vasopressin $1 \mathrm{~b}$ receptor gene impairs the attack component of social behavior in mice. Genes Brain Behav. 2006; 6(7): 653-660. [PubMed: 17284170]

129. Wersinger SR, Ginns EI, O'Carroll AM, et al. Vasopressin V1b receptor knockout reduces aggressive behavior in male mice. Mol Psychiatry. 2002; 7(9):975-984. [PubMed: 12399951]

130. Caldwell HK, Young WS 3rd. Persistence of reduced aggression in vasopressin $1 \mathrm{~b}$ receptor knockout mice on a more "wild" background. Physiol Behav. 2009; 97(1):131-134. [PubMed: 19419666]

131. Hussain, AA. Mechanism of nasal absorption of drugs. (0361-7742 (Print))

132. Zak PJ, Kurzban R, Matzner WT. Oxytocin is associated with human trustworthiness. Horm Behav. 2005; 48(5):522-527. [PubMed: 16109416]

133. Baumgartner T, Heinrichs M, Vonlanthen A, et al. Oxytocin shapes the neural circuitry of trust and trust adaptation in humans. Neuron. 2008; 58(4):639-650. [PubMed: 18498743]

134. Heinrichs M, von Dawans B, Domes G. Oxytocin, vasopressin and human social behavior. Front Neuroendocrinol. 2009; 30(4):548-557. [PubMed: 19505497]

135. Rimmele U, Hediger K, Heinrichs M, et al. Oxytocin makes a face in memory familiar. J Neurosci. 2009; 29(1):38-42. [PubMed: 19129382]

136. Domes G, Heinrichs M, Michel A, et al. Oxytocin improves "mind-reading" in humans. Biol Psychiatry. 2007; 61(6):731-733. [PubMed: 17137561]

137. Guastella AJ, Carson DS, Dadds MR, et al. Does oxytocin influence the early detection of angry and happy faces? Psychoneuroendocrinology. 2009; 34(2):220-225. [PubMed: 18848401]

138. Guastella AJ, Mitchell PB, Dadds MR. Oxytocin increases gaze to the eye region of human faces. Biol Psychiatry. 2008; 63(1):3-5. [PubMed: 17888410]

139. Thompson R, Gupta S, Miller K, et al. The effects of vasopressin on human facial responses related to social communication. Psychoneuroendocrinology. 2004; 29(1):35-48. [PubMed: 14575728]

140. Thompson RR, George K, Walton JC, et al. Sex-specific influences of vasopressin on human social communication. Proc Natl Acad Sci USA. 2006; 103(20):7889-7894. [PubMed: 16682649] 
141. Matson JL, Nebel-Schwalm M. Assessing challenging behaviors in children with autism spectrum disorders: a review. Res Dev Disabil. 2007; 28(6):567-579. [PubMed: 16973329]

142. Matson JL, Nebel-Schwalm MS. Comorbid psychopathology with autism spectrum disorder in children: an overview. Res Dev Disabil. 2007; 28(4):341-352. [PubMed: 16765022]

143. Crawley JN, Chen T, Puri A, et al. Social approach behaviors in oxytocin knockout mice: comparison of two independent lines tested in different laboratory environments. Neuropeptides. 2007; 41(3):145-163. [PubMed: 17420046]

144. Lee HJ, Caldwell HK, Macbeth AH, et al. Behavioural studies using temporal and spatial inactivation of the oxytocin receptor. Prog Brain Res. 2008; 170:73-77. [PubMed: 18655873]

145. Macbeth AH, Lee HJ, Edds J, et al. Oxytocin and the oxytocin receptor underlie intrastrain, but not interstrain, social recognition. Genes Brain Behav. 2009; 8(5):558-567. [PubMed: 19531157]

146. Wersinger SR, Temple JL, Caldwell HK, et al. Inactivation of the oxytocin and the vasopressin (Avp) $1 \mathrm{~b}$ receptor genes, but not the Avp 1a receptor gene, differentially impairs the Bruce effect in laboratory mice (Mus musculus). Endocrinology. 2008; 149(1):116-121. [PubMed: 17947352]

147. Winslow JT, Insel TR. The social deficits of the oxytocin knockout mouse. Neuropeptides. 2002; 26(2-3):221-229. [PubMed: 12359512]

148. Ferguson JN, Aldag JM, Insel TR, et al. Oxytocin in the medial amygdala is essential for social recognition in the mouse. J Neurosci. 2001; 21(20):8278-8285. [PubMed: 11588199]

149. Ferguson JN, Young LJ, Hearn EF, et al. Social amnesia in mice lacking the oxytocin gene. Nat Genet. 2000; 25:284-288. [PubMed: 10888874]

150. Modahl C, Green L, Fein D, et al. Plasma oxytocin levels in autistic children. Biol Psychiatry. 1998; 43(4):270-277. [PubMed: 9513736]

151. Green L, Fein D, Modahl C, et al. Oxytocin and autistic disorder: alterations in peptide forms. Biol Psychiatry. 2001; 50(8):609-613. [PubMed: 11690596]

152. Hollander E, Novotny S, Hanratty M, et al. Oxytocin infusion reduces repetitive behaviors in adults with autistic and Asperger's disorders. Neuropsychopharmacology. 2003; 28(1):193-198. [PubMed: 12496956]

153. Hollander E, Bartz J, Chaplin W, et al. Oxytocin increases retention of social cognition in autism. Biol Psychiatry. 2007; 61(4):498-503. [PubMed: 16904652]

154. Wu S, Jia M, Ruan Y, et al. Positive association of the oxytocin receptor gene (OXTR) with autism in the Chinese Han population. Biol Psychiatry. 2005; 58(1):74-77. [PubMed: 15992526]

155. Ylisaukko-oja T, Alarcon M, Cantor RM, et al. Search for autism loci by combined analysis of Autism Genetic Resource Exchange and Finnish families. Ann Neurol. 2006; 59(1):145-155. [PubMed: 16288458]

156. Jacob S, Brune CW, Carter CS, et al. Association of the oxytocin receptor gene (OXTR) in Caucasian children and adolescents with autism. Neurosci Lett. 2007; 417(1):6-9. [PubMed: 17383819]

157. Wermter AK, Kamp-Becker I, Hesse P, et al. Evidence for the involvement of genetic variation in the oxytocin receptor gene (OXTR) in the etiology of autistic disorders on high-functioning level. Am J Med Genet B Neuropsychiatr Genet. 2009

158. Gregory SG, Connelly JJ, Towers AJ, et al. Genomic and epigenetic evidence for oxytocin receptor deficiency in autism. BMC Med. 2009; 7(1):62. [PubMed: 19845972]

159. Kim SJ, Young LJ, Gonen D, et al. Transmission disequilibrium testing of arginine vasopressin receptor 1A (AVPR1A) polymorphisms in autism. Mol Psychiatry. 2002; 7(5):503-507. [PubMed: 12082568]

160. Wassink TH, Piven J, Vieland VJ, et al. Examination of AVPR1a as an autism susceptibility gene. Mol Psychiatry. 2004; 9(10):968-972. [PubMed: 15098001]

161. Yirmiya N, Rosenberg C, Levi S, et al. Association between the arginine vasopressin 1a receptor (AVPR1a) gene and autism in a family-based study: mediation by socialization skills. Mol Psychiatry. 2006; 11(5):488-494. [PubMed: 16520824]

162. Meyer-Lindenberg A, Kolachana B, Gold B, et al. Genetic variants in AVPR1A linked to autism predict amygdala activation and personality traits in healthy humans. Mol Psychiatry. 2009; 14(10):968-975. [PubMed: 18490926] 
163. American Psychiatric Association. Diagnostic and statistical manual of mental disorders: DSMIV-TR. 4. Washington, DC: American Psychiatric Association; 2000.

164. Lee R, Ferris C, Van de Kar LD, et al. Cerebrospinal fluid oxytocin, life history of aggression and personality disorder. Psychoneuroendocrinology. 2009; 34(10):1567-1573. [PubMed: 19577376]

165. Coccaro EF, Kavoussi RJ, Hauger RL, et al. Cerebrospinal fluid vasopressin levels: correlates with aggression and serotonin function in personality-disordered subjects. Arch Gen Psychiatry. 1998; 55(8):708-714. [PubMed: 9707381]

166. Virkkunen M, Kallio E, Rawlings R, et al. Personality profiles and state aggressiveness in Finnish alcoholic, violent offenders, fire setters and healthy volunteers. Arch Gen Psychiatry. 1994; 51(1):28-33. [PubMed: 7506516]

167. Caldwell HK, Stephens SL, Young WS 3rd. Oxytocin as a natural antipsychotic: a study using oxytocin knockout mice. Mol Psychiatry. 2009; 14(2):190-196. [PubMed: 18227836]

168. Feifel D, Reza T. Oxytocin modulates psychotomimetic-induced deficits in sensorimotor gating. Psychopharmacology (Berl). 1999; 141(1):93-98. [PubMed: 9952070]

169. Lee PR, Brady DL, Shapiro RA, et al. Social interaction deficits caused by chronic phencyclidine administration are reversed by oxytocin. Neuropsychopharmacology. 2005; 30(10):1883-1894. [PubMed: 15798779]

170. Bujanow W. Letter: is oxytocin an anti-schizophrenic hormone? Can Psychiatr Assoc J. 1974; 19(3):323. [PubMed: 4841051]

171. Bujanow W. Hormones in the treatment of psychoses. Br Med J. 1972; 4(5835):298. [PubMed: 5083904]

172. Beckmann H, Lang RE, Gattaz WF. Vasopressin-oxytocin in cerebrospinal fluid of schizophrenic patients and normal controls. Psychoneuroendocrinology. 1985; 10(2):187-191. [PubMed: 4034849]

173. Glovinsky D, Kalogeras KT, Kirch DG, et al. Cerebrospinal fluidoxytocin concentration in schizophrenic patients does not differ from control subjects and is not changed by neuroleptic medication. Schizophr Res. 1994; 11(3):273-276. [PubMed: 7910756]

174. Goldman M, Marlow-O'Connor M, Torres I, et al. Diminished plasma oxytocin in schizophrenic patients with neuroendocrine dysfunction and emotional deficits. Schizophr Res. 2008; 98(1-3): 247-255. [PubMed: 17961988]

175. Peskind ER, Raskind MA, Leake RD, et al. Clonidine decreases plasma and cerebrospinal fluid arginine vasopressin but not oxytocin in humans. Neuroendocrinology. 1987; 46(5):395-400. [PubMed: 3431654]

176. Raskind MA, Courtney N, Murburg MM, et al. Antipsychotic drugs and plasma vasopressin in normals and acute schizophrenic patients. Biol Psychiatry. 1987; 22(4):453-462. [PubMed: 3567260]

177. Feifel D, Priebe K. Vasopressin-deficient rats exhibit sensorimotor gating deficits that are reversed by subchronic haloperidol. Biol Psychiatry. 2001; 50:425-433. [PubMed: 11566159]

178. Feifel D, Melendez G, Priebe K, et al. The effects of chronic administration of established and putative antipsychotics on natural prepulse inhibition deficits in Brattleboro rats. Behav Brain Res. 2007; 181(2):278-286. [PubMed: 17559953]

179. Feifel D, Melendez G, Shilling PD. Reversal of sensorimotor gating deficits in Brattleboro rats by acute administration of clozapine and a neurotensin agonist, but not haloperidol: a potential predictive model for novel antipsychotic effects. Neuropsychopharmacology. 2004; 29(4):731738. [PubMed: 14760394]

180. Feifel D, Mexal S, Melendez G, et al. The brattleboro rat displays a natural deficit in social discrimination that is restored by clozapine and a neurotensin analog.

Neuropsychopharmacology. 2009; 34(8):2011-2018. [PubMed: 19322170]

181. Feifel D, Priebe K. The effects of cross-fostering on inherent sensorimotor gating deficits exhibited by Brattleboro rats. J Gen Psychol. 2007; 134(2):173-182. [PubMed: 17503693]

182. Aragona BJ, Liu Y, Cameron A, et al. Opposite modulation of social attachment by D1- and D2type dopamine receptor activation in nucleus accumbens shell. Horm Behav. 2003; 44:37. 
183. Aragona BJ, Liu Y, Curtis JT, et al. A critical role for nucleus accumbens dopamine in partner preference formation of male prairie voles (Microtus ochrogaster). J Neurosci. 2003; 23:34833490. [PubMed: 12716957]

184. Gingrich B, Liu Y, Cascio C, et al. Dopamine D2 receptors in the nucleus accumbens are important for social attachment in female prairie voles (Microtus ochrogaster). Behav Neurosci. 2000; 114(1):173-183. [PubMed: 10718272]

185. Aragona BJ, Liu Y, Yu YJ, et al. Nucleus accumbens dopamine differentially mediates the formation and maintenance of monogamous pair bonds. Nat Neurosci. 2006; 9(1):133-139. [PubMed: 16327783]

186. Northcutt KV, Lonstein JS. Social contact elicits immediate-early gene expression in dopaminergic cells of the male prairie vole extended olfactory amygdala. Neuroscience. 2009; 163(1):9-22. [PubMed: 19524021]

187. Bosch OJ, Nair HP, Ahern TH, et al. The CRF system mediates increased passive stress-coping behavior following the loss of a bonded partner in a monogamous rodent. Neuropsychopharmacology. 2009; 34(6):1406-1415. [PubMed: 18923404]

188. Lim MM, Liu Y, Ryabinin AE, et al. CRF receptors in the nucleus accumbens modulate partner preference in prairie voles. Horm Behav. 2007; 51(4):508-515. [PubMed: 17320879]

189. Ring RH, Schechter LE, Leonard SK, et al. Receptor and behavioral pharmacology of WAY-267464, a nonpeptide oxytocin receptor agonist. Neuropharmacology. 2010; 58(1):69-77. [PubMed: 19615387]

190. Ring RH. The central vasopressinergic system: examining the opportunities for psychiatric drug development. Curr Pharm Des. 2005; 11(2):205-225. [PubMed: 15638758]

191. Cirillo R, Gillio Tos E, Schwarz MK, et al. Pharmacology of (2S,4Z)-N-[(2s)-2-hydroxy-2phenylethyl]-4-(methoxyimino)-1-[(2'-methyl[1,1'-biphenyl]-4-yl) carbonyl]-2pyrrolidinecarboxamide, a new potent and selective nonpeptide antagonist of the oxytocin receptor. J Pharmacol Exp Ther. 2003; 306(1):253-261. [PubMed: 12660315]

192. Pitt GR, Batt AR, Haigh RM, et al. Nonpeptide oxytocin agonists. Bioorg Med Chem Lett. 2004; 14(17):4585-4589. [PubMed: 15357997] 


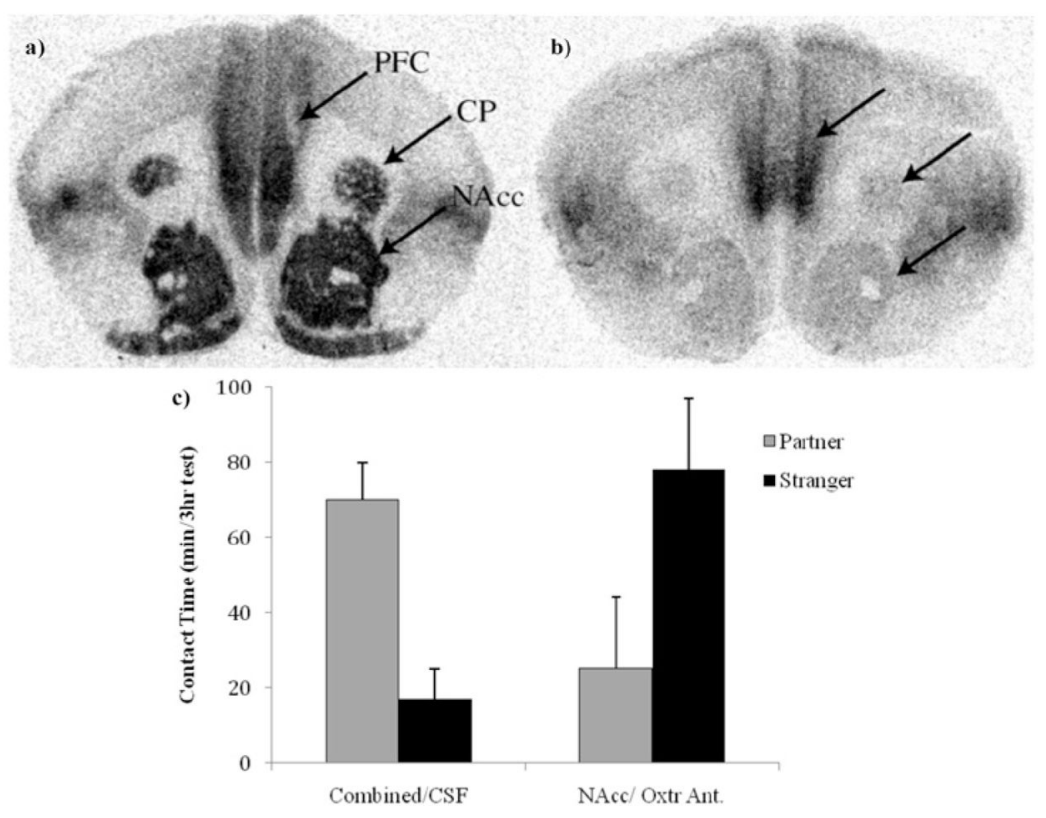

Figure 1.

In female prairie voles, oxytocin receptors (Oxtr) in the nucleus acumbens (NAcc) are thought be important for the formation of partner preference. Autoradiograms illustrating Oxtr distribution between monogamous female prairie voles (A) and nonmonogamous female meadow voles (B) demonstrate that female prairie voles have increased Oxtr binding in the prefrontal cortex (PFC), the caudate putamen (CP) and the NAcc compared to female meadow voles. Further, female prairie voles given a selective NAcc prior to and 12 hours into a 24 hour cohabitation period do not form a partner preference compared to females that received cerebral spinal fluid (CSF) into the PFC, $\mathrm{CP}$ and NAcc at the same time points (i.e., combined). (C). (A) and (B) were adapted from Hammock and Young. J Phil Trans R Soc B 2006; 361:2187-2198, ${ }^{3}$ C2006 with permission from The Royal Society. (C) was adapted from Young et al. Horm Behav 2001; 40:133-138, ${ }^{72}$ C2001 with permission from Elsevier. 


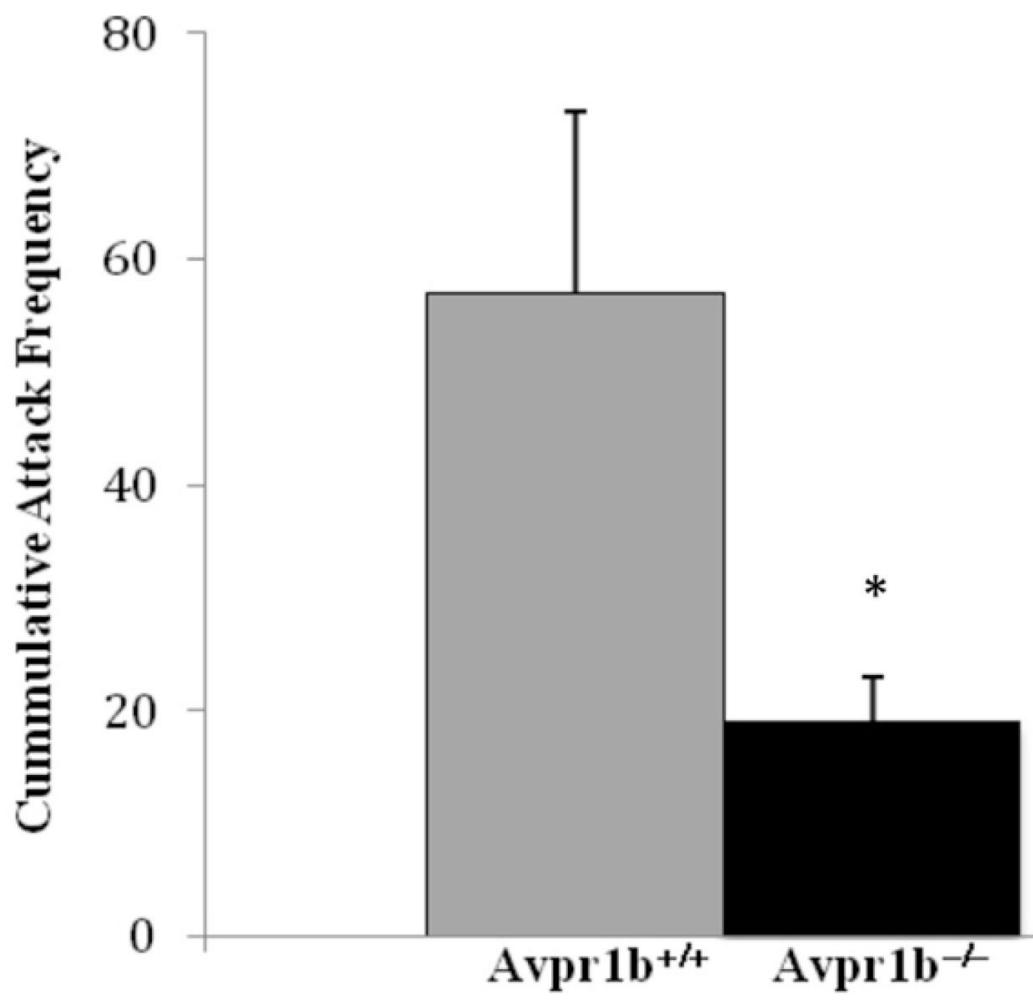

Figure 2.

Even when crossed with Mus musculus cantaneus, male Avpr1b knockout mice (Avpr1b ${ }^{-/-}$) have reduced aggression compared to wildtype $\left(\right.$ Avpr $\left.1 b^{+/+}\right)$controls; as measured by fewer attacks in a resident intruder behavioral test. Adapted from Caldwell and Young. Physiol Behav 2009; 97:131-134, ${ }^{130}$ C2009 with permission from Elsevier.) 